\title{
LASTING INFLUENCE OF ISABEL M. PRIESTLY
}

\author{
C. STUART HOUSTON, 863 University Drive, Saskatoon, Saskatchewan. \\ S7N OJ8
}

Mrs. Priestly had a profound influence on everyone who met her, and on many of her correspondents.

In 1939, just before my 12th birthday, knowing that I was going to be in Toronto with my parents en route to the World's Fair in New York City, Mrs. Priestly encouraged me to visit James L. Baillie, Jr., in the Royal Ontario Museum of Zoology in Toronto. Triumphantly I carried home to Yorkton surplus copies of every single issue of the Canadian FieldNaturalist with any mention of Saskatchewan, painstakingly sorted from the museum files by Baillie himself while I watched, amazed. Valuable stuff, which I read avidly and almost memorized!

Who in 1991 would treat a lad that age as a serious researcher with future potential? This sort of thing was typical of Jim Baillie (I have met at least five life-time birders who recounted similar stories from their boyhood), just as it was characteristic of Mrs. Priestly to treat students as adults.

The next summer, Vernon Barnes and I found the nest of a Black-billed Cuckoo on Wallace Avenue in Yorkton, on 28 June 1940, and were on hand to watch the third and last egg hatch. When we shared our excitement with Mrs. Priestly, she suggested that we write and tell A.G.
Lawrence, editor of "Chickadee Notes" in the Winnipeg Free Press. In the very next column, our names and our story appeared. We were in the public limelight.

Harvey Beck and I, in particular, tried our best to live up to Mrs. Priestly's expectations. Yet on at least one occasion I let her down. Her horror was evident when she first read the second issue (Volume 1, No. 2) of The Blue Jay in early 1943. A few hours before I sat down to type the stencil and then mimeograph the issue, I had gained some additional information concerning Jim Rogerson's Saltcoats Christmas Bird Count for 31 December 1942; without her knowledge, I added a phrase saying that the Sawwhet Owl found dead by Rogerson had been "stuffed." Goodness! Mrs. Priestly was upset. The Blue Jay was to be scientific - and "stuffed" wasn't the proper term at all. The owl had been "mounted."

Isabel Priestly indelibly influenced quite a few people. She changed my life completely. Through her disciples, she also affected many others. The final four items in this issue, by David Miller, David Wright, Dylan Von Kuster, and me, are offered to convey some idea of what Miller calls "the ripple effect" - over two more generations. Long may it last! 